Article

\title{
Generation and Activity Evaluation of a Mouse-Human Immunoglobulin G1 Chimeric Antibody to Histoplasma capsulatum HSP60
}

\author{
Ágata Nogueira D'Áurea Moura ${ }^{1}$, Scott J. Garforth ${ }^{2}$, Leandro Buffoni Roque da Silva ${ }^{3}$, Darien \\ Woodley'2, Filipe Vieira Barbalho' ${ }^{3}$, Jose A. Quiroz', Steven C. Almo' ${ }^{2}$, Jonathan R. Lai' ${ }^{2}$, Joshua \\ Daniel Nosanchuk ${ }^{4^{*}}$, and Carlos Pelleschi Taborda ${ }^{1,3 * *}$ \\ 1 Tropical Medicine Institute, Department of Dermatology, Faculty of Medicine, University of Sao Paulo, Sao \\ Paulo, 05403-000, Brazil; \\ 2 Department of Biochemistry, Albert Einstein College of Medicine, 1300 Morris Park Ave, Bronx, NY, 10461, \\ USA; \\ 3 Biomedical Sciences Institute, Department of Microbiology, University of São Paulo, Sao Paulo 05508-000, \\ Brazil. \\ 4 Departments of Medicine (Division of Infectious Diseases) and Microbiology and Immunology, Albert \\ Einstein College of Medicine, New York, NY, 10461, USA; \\ * Correspondence: taborda@usp.br and josh.nosanchuk@einsteinmed.org \\ \# JDN and CPT equally contributed with the article.
}

\begin{abstract}
Heat shock proteins (Hsps) are highly conserved molecules that are constitutively expressed and upregulated in response to physiological stress conditions. These immunogenic chaperones can have essential functions in fungi, particularly in dimorphic pathogens. Histoplasma capsulatum and Paracoccidioides species are dimorphic fungi that are the causative agents of histoplasmosis and paracoccidioidomycosis, respectively, which are systemic mycoses with significant rates of morbidity and mortality. Current treatment consists of long-term antifungal agents, and there is an urgent need for new therapeutic approaches with higher efficacy, lower toxicity, better biodistribution and improved selectivity. We engineered an immunoglobulin G1 (IgG1) isotype chimeric mouse-human monoclonal antibody, titled ch-MAb 4E12, from the parental IgG2a MAb 4E12, a monoclonal antibody to H. capsulatum Hsp60 that is protective in experimental histoplasmosis and paracoccidioidomycosis models elicited by $H$. capsulatum var. capsulatum and Paracoccidioides lutzii, respectively. The ch-MAb 4E12 increased phagolysosomal fusion and enhanced the yeasts uptake by PMA differentiated human THP1 macrophage cells in vitro. At low concentrations, the chimeric antibody significantly reduced the pulmonary and splenic fungal burden compared to an irrelevant antibody or no treatment. These results are the first to show that a chimeric mouse-human antibody can modify infection caused by dimorphic fungi.
\end{abstract}

Keywords: Mouse-Human Chimeric Antibody; Immunotherapy; Infectious diseases; Histoplasmosis; Paracoccidioidomycosis; Histoplasma capsulatum; Paracoccidioides lutzii

\section{Introduction}

Dimorphic fungi are a family of human fungal pathogens with a worldwide distribution that are typically characterized by temperature-induced morphological transition from filamentous form in the environment to yeast during infection (1). Although the incidence data of infections by dimorphic fungi are generally inaccurate due to under-diagnosis and under-reporting, endemic mycosis is believed to be responsible for around 65,000 life-threatening cases each year worldwide 
(2). Between the most important human systemic mycosis caused by dimorphic fungus are Histoplasmosis due H. capsulatum, primarily prevalent in South, Central and North Americas countries (3), and Paracoccidioidomycosis (PCM) due Paracoccidioides spp., localized to Latin America (4) and predominantly reported in Brazil (5). In addition to dimorphism, these pathogens share important attributes such as immunodominant antigens, as well as clinical and pathological characteristics (6).

Major advances in the treatment of fungal infections were made in the 1990s after the introduction of second-generation azoles, echinocandins, and lipid formulations of amphotericin B $(\mathrm{AmB})$, however, drug development has largely stalled since then (7). A limited number of antifungal agents are approved for invasive fungal infections (8), currently the main antifungal class directed to systemic mycoses therapy are polyenes, azoles, and echinocandins (9). However, echinocandins are not active against dimorphic fungi. Most patients with invasive fungal diseases receive weeks to months or even years of antifungal treatment (2). Therapies for invasive infection have different restrictions such as requiring intravenous administration, toxicities, and drug interactions. High costs due to hospitalizations $(9,10)$ and increased drug resistance also are important considerations (11). In addition to the need for the development of new antifungal agents, approaches that modulate the immune system and activate protective mechanisms against pathogenic fungi have shown promise (1). Monoclonal Antibodies (MAbs) represent an approach that has shown great potential in preclinical evaluation of infectious diseases treatment, both in vitro and in vivo models. Many of these Mabs, however, have not reached clinical trials. Protective Mabs have been identified against several important fungal pathogens, such as Aspergillus fumigatus, Candida albicans, Cryptococcus neoformans, Histoplasma capsulatum, Paracoccidioides spp. And Sporothrix schenckii (reviewed in $(1,4,12)$ ). A MAb to the polysaccharide capsule of $C$. neoformans completed a phase 1 clinical trial, wich resulted in pharmacological effect evidence as demonstrated by a reduction in the serum antigen titers (13).

Heat shock proteins (Hsp) are conserved immunodominant antigens that can induce humoral and cell-mediated immune responses during infection, making them a potential target for therapeutic Mabs (14,15). Hsp60 is a chaperone with a high level of conservation among dimorphic fungi, particularly between $H$. capsulatum and Paracoccidioides spp. (6). Guimarães et al. produced the MAb 4E12 against recombinant HSP60 from $H$. capsulatum. This IgG2a subclass MAb modified the course of experimental murine histoplasmosis, reducing inflammation, preventing intracellular replication and prolonging the survival of mice (16). Thomaz et al. also demonstrated a protective effect of MAb 4E12 against $P$. lutzii in a murine experimental PCM model. Passive administration of the MAb significantly reduced fungal burden and damage to lung tissue due to PCM, and also increased phagocytosis of $P$. lutzii yeasts in vitro (17). In both fungal infections, MAb 4E12 was associated with a Th1 response $(16,17)$.

Although several Mabs of murine origin have been approved for clinical use, their applicability is limited since treated patients frequently develop Human Anti-Mouse Antibodies (HAMA). These antibodies can reduce the effectiveness of the treatment and increase the Mabs elimination rate due to the formation of immune complexes. A simple alternative is the construction and production of human-mouse chimeric Monoclonal Antibodies (ch-Mabs). These molecules have a human constant region and a murine variable region, composed by heavy chain $(\mathrm{VH})$ and light chain (VL). Maintaining the variable region preserves the affinity and specificity of the parental murine MAb, while changing the constant region to human sequences significantly reduces immunogenicity (18). In this work Mrna was extracted from the MAb 4E12-producing hybridoma for the production of chimeric antibody by genetic recombinant techniques. The ch-MAb was evaluated for affinity, specificity and effectiveness to $H$. capsulatum and Paracoccidioides. 
3 of 19

\section{Materials and Methods}

\subsection{Fungal strains and growth conditions}

H. capsulatum var. capsulatum strain G217B yeast cells were grown in Ham's F-12 medium or BHI Broth supplemented with $0.1 \%$ cysteine and $1 \%$ glucose at $37^{\circ} \mathrm{C}$ and $150 \mathrm{rpm}$ shaking for 3 days. $P$. lutzii strain $\mathrm{Pb} 01$ and P. brasiliensis strain Pb18 yeast cells were grown in Fava Netto Broth at $37^{\circ} \mathrm{C}$ and $150 \mathrm{rpm}$ shaking for 5 days. Cell viability was determined by Trypan blue staining (Sigma, St. Louis, MO) and counting on a hemocytometer after washing with phosphate-saline buffer at $\mathrm{pH}$ 7.2.

\subsection{Extraction and quantification of fungal proteins}

Yeast cells were washed in $10 \mathrm{mM}$ Tris-HCl buffer, $\mathrm{pH}$ 7.4, and disrupted by mechanical lysis (5 min) in the presence of protease inhibitors (Sigmafast Cocktail Tablets, EDTA-Free). Cells suspension were harvested by centrifugation and the supernatant with cytosolic proteins was collected. Decanted cells were washed with sterile distilled water and then with a decreasing concentration gradient of $1 \mathrm{mM}$ Phenylmethylsulfonyl Fluoride (PSF) Saline buffers (5, 3 and 1\% $\mathrm{NaCl}$ ). After boiling in a $50 \mathrm{mM}$ Tris-HCL buffer (0.1 M EDTA, 2\% SDS, $10 \mathrm{mM} \mathrm{DTT})$, pH 8.0, for 10 min at $100^{\circ} \mathrm{C}$, cells suspension were harvested by centrifugation and the supernatant with surface proteins was collected. The samples were quantified by spectrophotometry at $280 \mathrm{~nm}$ on a NanoDrop 2000 equipment (Thermo Scientific), readings were made in triplicate. All centrifugation steps were performed 3 times at $4000 \mathrm{rpm}, 4^{\circ} \mathrm{C}$, for $10 \mathrm{~min}$. Samples were kept on ice throughout the procedure.

\subsection{Animals}

Male C57B16 mice strain (6-8 weeks). Experimental histoplasmosis was performed according to the Ethics Committee on the Use of Animals of the Faculty of Medicine, University of Sao Paulo (CEUA-FMUSP) guidelines, protocol number 041/16.

\subsection{Recombinant Protein expression and purification}

The pET vector harboring the H. capsulatum var. capsulatum Hsp60 gene was isolated from Escherichia coli cells previously transformed with the plasmid (19). Cloned bacterial cells were a gift from G. Deepe (University of Cincinnati, Cincinnati, OH) to the Nosanchuk laboratory (Albert Einstein College of Medicine, Bronx, NY) (16), where part of this study were developed. After propagation, the ligated Plasmid DNA (50 ng) was incubated for $30 \mathrm{~min}$ on ice, followed by transformation into $E$. coli strain BL21 DE3 chemically competent cells $(25 \mu \mathrm{L})$ by heat shock at $42^{\circ} \mathrm{C}$ for $90 \mathrm{sec}$ and mixed with $800 \mu \mathrm{L}$ of Super Optimal broth with Catabolite repression (SOC) medium. The transformants were incubated at $37^{\circ} \mathrm{C}$ at $250 \mathrm{rpm}$ shaking and seeded on LB agar plates with ampicillin $(100 \mu \mathrm{g} / \mathrm{mL})$.

Inocula prepared with picked colonies were incubated at $37^{\circ} \mathrm{C}$ and $250 \mathrm{rpm}$ shaking to reaching 0.6-0.8 Optical Density (OD) measured at $600 \mathrm{~nm}$ wavelength. The protein expression was induced by $1 \mathrm{mM}$ IPTG for $6 \mathrm{~h}$. Cells were harvested by $8000 \mathrm{rpm}$ centrifugation at $4^{\circ} \mathrm{C}$ for $30 \mathrm{~min}$ and resuspended in 1X PBS $10 \mathrm{mM}$ imidazole. Lysis was performed in an Ultrasonic Cell Disruptor (10-second pulses, 59 -second intervals, $60 \%$ amplitude). The samples analysis was performed by SDS-PAGE.

The recombinant protein, solubilized in lysis buffer, was purified by Nickel Column Affinity Chromatography, charged with Ni-NTA Resin (Thermo Fisher Scientific Inc, New York, NY), and using a discontinuous imidazole concentration gradient $(100 \mathrm{mM}, 250 \mathrm{mM}$ and $500 \mathrm{mM})$ in $20 \mathrm{mM}$ $\mathrm{PO} / 500 \mathrm{mM} \mathrm{NaCl}$ buffer, $\mathrm{pH}$ 8.0. Before elution, the column was washed with 3 column volumes of $10 \mathrm{mM}$ imidazole $1 \mathrm{X}$ PBS. The eluted fractions containing pure protein were identifed by colorimetric 
reaction using 1X Bradford solution and by SDS-PAGE. The protein concentration measurements were made in Nanospectrophotometer, at $280 \mathrm{~nm}$.

\subsection{Murine Monoclonal Antibody}

The MAb 4E12 to H. capsulatum HSP60 was previously characterized (16). The hybridomas were maintained at $37^{\circ} \mathrm{C}, 5 \% \mathrm{CO}_{2}$, in RPMI 1640 medium supplemented with $10 \%$ Fetal Bovine Serum (FBS), 25mM HEPES, 1X MEM Amino Acids, and 1X Sodium Pyruvate, for genetic stability tests by ELISA. After cell expansion, the culture supernatant was collected and concentrated in an Ultrafiltration System with Discs 100 kDa NMWL (Merck Millipore).

To confirm the isotype (IgG2a), the supernatant containing the MAb was added to the 96-well High Bind Microplate (Corning) previously coated with capture antibody (Goat Anti-Mouse IgG Unconjugated), and after blocking with 1X Phosphate-buffered saline (PBS) plus 3\% Bovine serum albumin (BSA). Detection was performed with secondary antibodies anti-immunoglobulin G1, G2a, G2b and G3, conjugated with Alkaline Phosphatase (AP). To measure the MAb concentration a curve (from 1: 100) was compared with a IgG2a standard curve (from $10 \mu \mathrm{g} / \mathrm{ml}$ ). Dilutions were made at a ratio of 3. Detection was performed with Goat Anti-Mouse IgG Secondary Antibody AP conjugated (1:2500). To analyze the mAb reactivity by the target antigen, a microplate previously

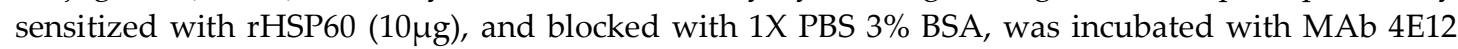
$(10 \mu \mathrm{g} / \mathrm{ml})$. Detection was performed with Goat Anti-Mouse IgG2a Secondary Antibody AP conjugated (1:2500).

In all assays the detection with a secondary antibody were followed by washing with Alkaline Phosphatase Buffer Solution $(0.1 \mathrm{M} \mathrm{NaCl}, 50 \mathrm{mM} \mathrm{MgCl} 2,0.1 \mathrm{M}$ Tris-HCl, $\mathrm{pH}$ 9.5) and colorimetric reaction with NBT/BCIP Substrate Solution 1:1 (Nitro blue tetrazolium/5-Bromo-4-chloro-3-indolyl phosphate). The incubation steps $\left(1 \mathrm{~h}\right.$ at $\left.37^{\circ} \mathrm{C}\right)$ were intercalated by 3 washes $(5 \mathrm{~min})$ with $1 \mathrm{X}$ PBS $0.05 \%$ Tween 20 . Readings were performed by spectrophotometry at $450 \mathrm{~nm}$.

\subsection{Amplification of $V H$ and $V L$ Regions}

Hybridoma cells were counted and collected up to $3 \times 10^{6}$ cells suspension by centrifugation ( 5 min at 200xg). The cells were washed twice with 1X PBS and suspended in lysis buffer to disruption in vortex for 15 seconds. Lysate in 100\% ethanol and free of genomic DNA (by passing through a 25 gauge needle) was loaded onto a spin column to RNA extraction using miRCURY RNA Isolation Kit - Cell \& Plant (EXIQON). iScript cDNA Synthesis Kit (Bio-Rad) was used to produce the first-strand cDNA from RNA template.

The resulting cDNA was screened with two sets of primer pairs designed to ascertain which Kabat gene family heavy and light chains (20) were derived from, designed according with Nicholls et al. (1993) (21). The primers include $30 \mathrm{bp}$ cloning vector overlap sequence plus $7 \mathrm{bp}$ restriction sites, and the leader sequence ACTCC encoding the leader peptide end, as overhangs (important to ensure no frameshifting). Having identified the most effective primers for Heavy chain (F-5'-aatgacatccactttgcctttctctccacaggcgegcactccGAGGTTCAGCTTCAGCAGTCT-3' R-5'-ccagggggaagaccgatgggccettggtgctagcTGAGGAGACTGTGAGAGTGGTGCCTTGRCCCCA-3') and Light chain (F-5'-aatgacatccactttgcctttctctccacaggcgcgcactccGACATTGTGATGACYCARTCT-3' and R-5'-gggaagatgaagacagatggtgcagccaccgtacgTTTTATCTCCAGCTTKGTSCC-3'), the variable regions were amplified with the Phusion High-Fidelity PCR Master Mix Kit (Thermo Scientific). PCR products were analysed by electrophoresis on a $1 \%$ agarose gel at $80 \mathrm{~V}$. DNA bands around 400 $\mathrm{bp}$, as determined by GeneRuler $1 \mathrm{~kb}$ DNALadder (ThermoScientific), were purified using QIAquick Gel Extraction Kit (QIAGEN). 
5 of 19

\subsection{Cloning potential $V H$ and $V L$ into expression vector and Sequencing}

The vectors pMAZ-VH and pMAZ-VL, modified from Mazor et al. (2007) (22), were kindly provided by Dr Jonathan R. Lai (Albert Einstein College of Medicine, Bronx, NY, USA). For the cloning process, the vectors ( $600 \mathrm{ng}$ ) were linearized by enzymatic digestion at the insertion sites with BssHII and NheI (pMAZ-VH) in NEB 2.1 buffer or BssHII and BsiWI restriction enzymes (pMAZ-VL) in NEB 3.1 buffer $\left(10 \mu \mathrm{L}\right.$ final volume reaction), for $2 \mathrm{~h}$ at $37^{\circ} \mathrm{C}$. Potential $V H$ and $V L$ amplified and purified products were ligated into the respective vectors ( 0.5 pmols fragments total amount), for $1 \mathrm{~h}$ at $50^{\circ} \mathrm{C}$, using Gibson Assembly Master Mix. Ligated products (50 ng) were transformed into chemically competent $E$. coli DH5-alpha cells $(25 \mu \mathrm{L})$ by heat shock method, for 90 sec at $42^{\circ} \mathrm{C}$. Transformants were shaking $(250 \mathrm{rpm})$ for $1 \mathrm{~h}$ at $37^{\circ} \mathrm{C}$ and seeded on LB agar plates with ampicillin $(100 \mu \mathrm{g} / \mathrm{mL})$.

Inocula ( $5 \mathrm{~mL}$ each one) prepared with picking transformant colonies were incubated at $37^{\circ} \mathrm{C}$ and $250 \mathrm{rpm}$ shaking, overnight. Cells harvested by centrifugation (6800xg) for $3 \mathrm{~min}$ at room temperature were resuspended in lysis buffer for plasmid DNA propagation using QIAprep Miniprep kit (QIAGEN). The cloning sites and insert size were checked by restriction enzyme digestion and $1 \%$ agarose gel electrophoresis analysis. Sanger method was used to sequence pre-mixed recombinant plasmids with CMV-F primer (5'-CGCAAATGGGCGGTAGGCGTG-3') by GENEWIZ. Correct sequences were verified by aligning with the expected match and IgBLAST search were performed against Nucleotide Sequence Human and Mouse database (NCBI) (23). IMGT/V-QUEST tool was used to compare immunoglobulin germline $\mathrm{V}$ gene and rearranged V-J and V-D-J genes with reference directory sets (24). The signal peptide at $5^{\prime}$ end of $\mathrm{VH}$ and VL was identified by SignaIP (25).

\subsection{Mouse-Human Chimeric IgG1 expression and purification}

A $600 \mathrm{ml}$ culture of suspension Freestyle 293-F cells (Gibco) in Freestyle Expression media (Gibco) were transfected with the pMaz vectors encoding the heavy and light chains at an equimolar ratio. Cells were transfected at a density of $1 \times 10^{6}$ cells $/ \mathrm{mL}$ uisng PEI $(2 \mu \mathrm{g} / \mathrm{ml}$ culture $)$ and $500 \mathrm{ng} / \mathrm{ml}$ plasmid DNA in PBS. The cells were incubated at $37^{\circ} \mathrm{C}$ with shaking at $110 \mathrm{rpm}$ and $8 \% \mathrm{CO}_{2}$. Valproic acid (VPA) was added to $3 \mathrm{mM}$ final concentration $24 \mathrm{~h}$ post transfection, and the supernatant was harvested 6 days post-transfection by centrifugation at 1000xg for $5 \mathrm{~min}$.

The small-scale antibody purification was performed using disposable columns (BioRad) packed with protein A resin. After washing with 1X PBS (3 times), $100 \mu$ l elution fractions in $0.1 \mathrm{M}$ citric acid buffer ( $\mathrm{pH} 3$ ), were collected in tubes containing $10 \mu \mathrm{l}$ of Tris $1 \mathrm{M}$ buffer ( $\mathrm{pH}$ 9.0). Clarified supernatant from large scale $(600 \mathrm{ml})$ culture was applied to a $5 \mathrm{ml}$ MabSelect SuRe (GE) column on an ÄKTA Xpress FPLC (GE Healthcare) followed by gel filtration chromatography (Superdex S200 26/60, GE) in 1 X PBS. Purified antibody yield was calculated by absorbance at $280 \mathrm{~nm}$. SDS-PAGE analysis of the purified antibody was performed on $4-12 \%$ gradient Bis-Tris PAGE gels (Criterion $\mathrm{XT}$, BioRad) under reducing and non-reducing conditions..

\subsection{Western blot analysis}

Reactivity assay of ch-MAb 4E12 was performed against recombinant HSP60 (10 $\mu \mathrm{g})$ and HSP60 from yeast cells protein extracts $(30 \mu \mathrm{g})$, mouse-MAb $4 \mathrm{E} 12$ was used as a positive control. Samples were transferred from $12 \%$ polyacrylamide gel to nitrocellulose membrane (GE Healthcare) using the Semi-Dry Electrophoretic Transfer Cell System (BioRad), for $15 \mathrm{~min}$ at 15V. After overnight blocking in 1X PBS 3\% BSA, the membranes were incubated for $1 \mathrm{~h}$ with primary antibodies $10 \mu \mathrm{g}$ in 1X PBS 1\% BSA. Detection was performed with Goat Anti-Human, or Anti-Mouse, IgG Secondary Antibody HRP conjugated (1:2500) for $1 \mathrm{~h}$. The reactions was measured by chemiluminescence with 
ECL Kit (Hydrogen peroxide + Luminol) in a CCD Photo Documentation System.The incubation steps were intercalated by 3 washes ( 5 min) with 1 X PBS 0.05\% Tween 20.

\subsection{Titration of ch-MAb $4 E 12$}

A High Binding 96-well ELISA microplate (Corning) was coated with recombinant HSP60 (10 $\mu \mathrm{g})$ overnight at $4^{\circ} \mathrm{C}$. Dilutions of ch-MAb $4 \mathrm{E} 12$, from $0,1 \mathrm{mg} / \mathrm{mL}(10 \mu \mathrm{g})$ using a rate of 2 , were incubated with the protein for $1 \mathrm{~h}$ at $37^{\circ} \mathrm{C}$. Mouse-MAb $4 \mathrm{E} 12$ (same dilutions) was used as positive control and for reactivity comparison. Detection was performed with Goat Anti-Human, or Anti-Mouse, IgG Secondary Antibody HRP conjugated (1:2500) for $1 \mathrm{~h}$. Colorimetric reaction was performed using 3,3',5,5'-Tetramethylbenzidine Substrate solution (TMB) and Hydrogen peroxide. The incubation steps were intercalated by 3 washes $(5 \mathrm{~min}$ ) with 1X PBS $0.05 \%$ Tween 20 . Reading was performed in Epoch Spectrophotometer at $450 \mathrm{~nm}$, after adding $\mathrm{H} 2 \mathrm{SO} 41 \mathrm{M}$ stop solution.

\subsection{Phagocytosis assay}

Heat inactivated $\left(90 \mathrm{~min} / 100^{\circ} \mathrm{C}\right)$ and $1 \%$ CalcoFluor stained $\left(10 \mathrm{~min} / 25^{\circ} \mathrm{C}\right)$ yeast cells $\left(1 \times 10^{6}\right.$ cells/well) were opsonized or not (overnight at $4^{\circ} \mathrm{C}$ ) with irrelevant antibody, anti- $H$. capsulatum serum, anti-P. lutzii serum, or ch-MAb $4 \mathrm{E} 12(5,10 \mathrm{or} 50 \mu \mathrm{g})$, and co-cultured with macrophages ( $2 \times 10^{5}$ cells/well) previously differentiated from a Human Monocytic Cell line (THP1) with Phorbol 12-myristate 13 -acetate (100 mM PMA) for 24 hours at $37^{\circ} \mathrm{C} / 5 \% \mathrm{CO}_{2}$.

After washing with $0.15 \mathrm{M}$ alpha-mannopyranoside, the cells were fixed in methanol (30 $\min / 25^{\circ} \mathrm{C}$ ) for differential staining with Giemsa $20 \mathrm{x}$, or incubated with Anti-Human IgG-FITC antibody $\left(60 \mathrm{~min} / 37^{\circ} \mathrm{C}\right)$ for fluorescence detection by lysosome labeling according with Lysosomal Staining Kit Cytopainter (abcam). The macrophages were stimulated or not with IFN-gamma 2.5 $\mu \mathrm{g} / \mathrm{mL}$ per well for $16 \mathrm{~h}\left(37^{\circ} \mathrm{C} / 5 \% \mathrm{CO}_{2}\right)$. Co-culture was performed in supplemented RPMI ( $10 \% \mathrm{SFB}$, 1\% AAS, 1X Penicillin-Streptomycin). Phagocytic capacity was analyzed after 2, 4, 6 and 8 hours of co-culture.

\subsection{Cytotoxicity MTT assay}

Macrophages differentiated from monocytes THP1 strain (dilutions from 1x104 cells/well) were seeded in a 96-well microtiter plate and treated with ch-MAb 4E12 $(1,5,10,50$, or $100 \mu \mathrm{g})$ for $24 \mathrm{~h}$ at $37^{\circ} \mathrm{C} / 5 \% \mathrm{CO}_{2}$. Negative control received no treatment. The cells were incubated with MTT $0.5 \mathrm{mg} / \mathrm{mL}$ per well for $4 \mathrm{~h}$ at $37^{\circ} \mathrm{C} / 5 \% \mathrm{CO}_{2}$. Formazan crystals were solubilized with DMSO $50 \mu \mathrm{L} /$ well for 30 $\min$ at $37^{\circ} \mathrm{C} / 5 \% \mathrm{CO}_{2}$. Titrations were performed at a ratio of 2 . Readings were performed in Epoch Spectrophotometer at $540 \mathrm{~nm}$.

\subsection{Acute toxicity assay in Galleria Mellonella}

The larvae of G. mellonella are maintained for growth and reproduction at the Institute of Biomedical Sciences II, USP. Groups of 16 larvae each, weighing from 120 to $200 \mathrm{mg}$, were injected with $10 \mu \mathrm{L}$ of samples in the third proleg on the right side using a micro-syringe (Hamilton co., Reno, $\mathrm{NV}$, EUA). Larvae were treated with the mouse-human ch-MAb 4E12 1, 5, 10, 25, and $50 \mu \mathrm{g}$, or with the parental MAb 4E12 $5 \mu \mathrm{g}$. The negative control received only PBS1X. The larvae were incubated at room temperature $\left(25^{\circ} \mathrm{C}\right)$ and evaluated daily for 7 days, the experiments were carried out in duplicate. Death was defined as the complete loss of mobility, including the sequence of a physical stimulus with a plastic pipette. 
7 of 19

\subsection{CFU study}

Immunization was performed intraperitoneally with $1,5,10$ or $25 \mu \mathrm{g}$ IgG1 ch-MAb to $H$. capsulatum var. capsulatum Hsp60, with an irrelevant IgG MAb isotype, or with $5 \mu \mathrm{g}$ of the parental IgG2a MAb 4E12 as positive control, two hours before infection by intranasal injection. A control group received no treatment. The antibodies were screened for the endotoxin absence using the QCL Chromogenic LAL- Kinetic Assay for sample preparation - and -Endpoint Assay for reading (Lonza, Walkersville, MD).

Infections were performed using a $5 \times 10^{6} \mathrm{H}$. capsulatum var. capsulatum yeast cells in an inoculum of $10 \mu \mathrm{l}$ per animal. Mice were anesthetized with $100 \mathrm{mg} / \mathrm{kg}$ Ketamine and $10 \mathrm{mg} / \mathrm{kg}$ Xylazine, and yeast cells were administered intranasally. Animals were euthanized at day 7 postinfection, the remaining lung and spleen tissues were weighed, macerate, and homogenized separately in $2 \mathrm{~mL}$ and $1 \mathrm{~mL}$ of PBS, respectively. The lung homogenates were diluted 40 and 20 times and plated onto brain heart infusion blood agar, the spleen homogenates were plated directly. The cultures were incubated at $37^{\circ} \mathrm{C}$ to determinate the CFU numbers. Each group contained five mice, and the experiments were carried out in duplicate.

\subsection{Statistical analysis}

Graph Pad Prism 7.1 software was used for phagocytosis, toxicity and CFU number assays statistical analysis. Datasets were compared by one-way ANOVA and a Tukey's post-test.

\section{Results}

\subsection{Histoplasma capsulatum HSP60 is an immunogenic protein}

Induction for $3 \mathrm{~h}$, in LB medium, with $1 \mathrm{mM} \mathrm{IPTG}$, at $37^{\circ} \mathrm{C}$, was the ideal condition to produce the HSP60 protein in the E. coli clone with higher expression level (Figure S1). The protein sample with the highest purity degree, obtained by affinity chromatography, was eluted in the presence of $250 \mathrm{mM}$ imidazole (Figure S2). The protein suspension was used to sensitize microplates for $\mathrm{mAb}$ $4 \mathrm{E} 12$ reactivity and isotyping assays. The monoclonal antibody identified as IgG2a recognized and bound HSP60.

\subsection{Forward and Reverse primers selection}

A set of primer pairs were used to amplify the variable region sequences in the cDNA from $\mathrm{mAb} 4 \mathrm{E} 12-$ producing hybridoma (Figure 1). Fragments amplified using Forward-VL I/III and Reverse-CL UNI, for light chain primers, and Forward-VH V and Reverse-CH UNI, for heavy chain primers, were selected after PCR purification (Figure 2). The primers used to screen the hybridoma cDNA are listed in Table S1. 

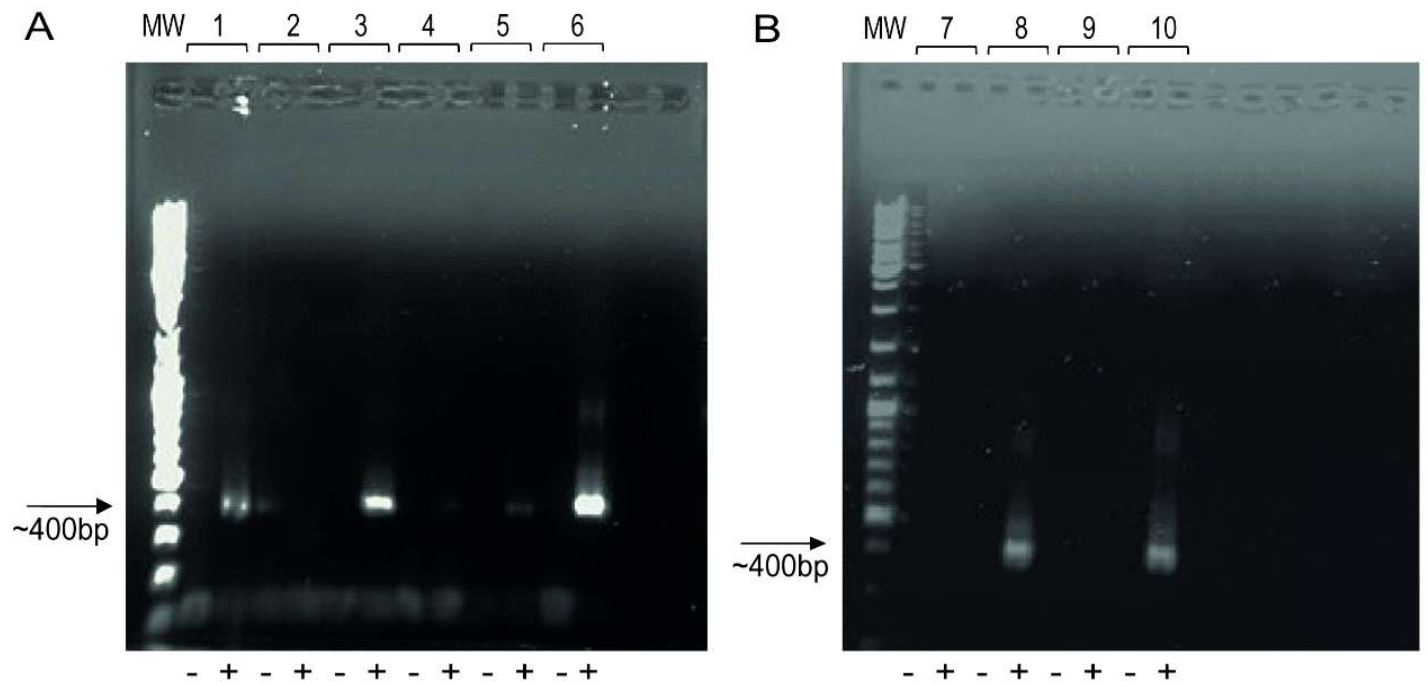

Figure 1. Amplification of hybridoma cDNA light and heavy chains using PCR primers designed according on the Kabat gene family. Electrophoresis analysis detected fragments efficiently amplified in reactions for light chain (1, 3 and 6) and for heavy chain (8 and 10). A. Light chain sequences; B. Heavy chain sequences. MW: Invitrogen $1 \mathrm{~Kb}$ Plus DNA Ladder. 1: (VL-I/III; CL-UNI); 2: (VL-IV/VI; CL-UNI); 3: (VL-Ila; CL-UNI); 4: (VL-IIb; CL-UNI); 5: (VL-Va; CL-UNI); 6: (VL-Vb; CL-UNI); 7: (VH-I; CH-UNI); 8: (VH-II; CH-UNI); 9: (VH-III; CH-UNI); 10: (VH-V; CH-UNI).

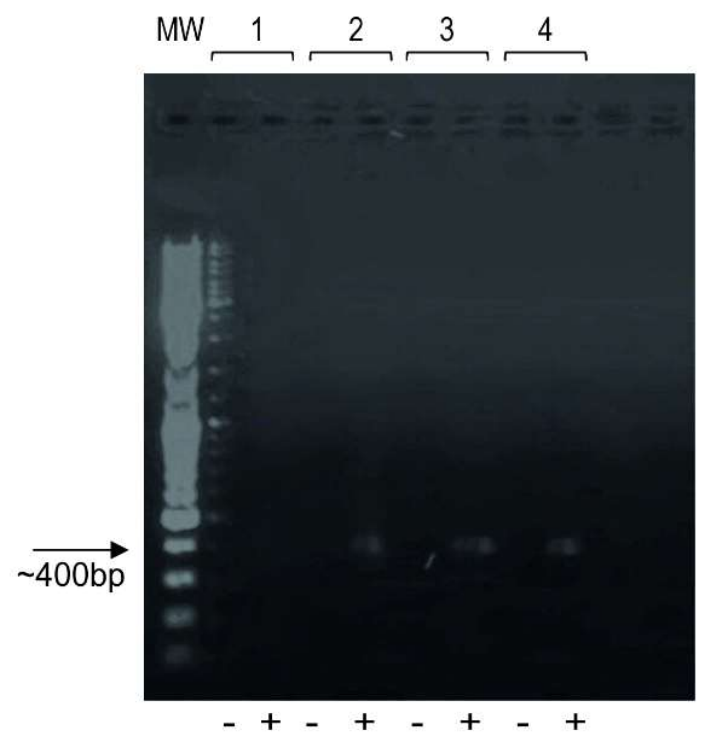

Figure 2. Variable Region PCR products purification. Fragments of approximately 400 bps were detected. MW: Invitrogen $1 \mathrm{~Kb}$ Plus DNA Ladder. 1: (VH-II; CH-UNI); 2: (VH-V; CH-UNI); 3: (VL-I/III; CL-UNI); 4: (VL-Ila; CL-UNI).

\subsection{The efficient assembly of VR fragments with IgH and IgL expression vectors}

PCR amplified VL or VH genes from MAb 4E12-producing hybridoma cDNA were cloned into pMAZ-VL or pMAZ-VH vectors, respectively. Plasmids were isolated from positive clones and, the fragment sizes and correct insertion in the restriction sites, were confirmed by double digestion (Figure 3). The selected plasmids sequencing was performed by GENEWIZ. BLAST search tool was used to the nucleotide sequences alignment, confirming more than $90 \%$ homology average with the respective murine immunoglobulins variable regions of known sequence. CPPC motif coding region 
was screened in the heavy chain sequence. The Cys residues are important to stabilize the antibodies tertiary structures, forming disulfide bonds by thiol groups oxidation. V-gene and J-gene heavy chain alignment with the Mus musculus species Ig sequences resulted in $90.62 \%$ and $84.78 \%$ identity, respectively. Light chain alignment analyzes resulted in V-region low identity (78.49\%), which may indicate potential nucleotides insertions or deletion.
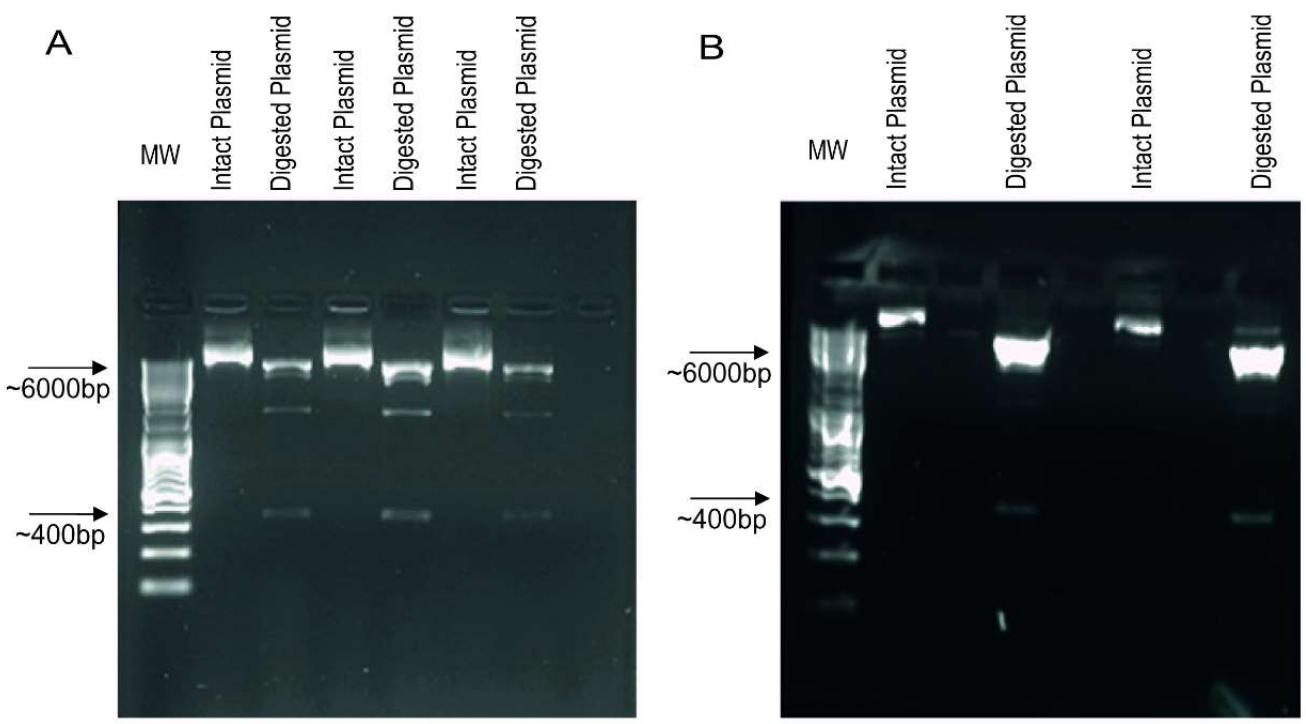

Figure 3. Confirmation of variable region fragments insert by restriction enzymes digestion. The plasmids were linearized and the resulting fragments were analyzed by electrophoresis. Double digestion resulted in two bands, the $400 \mathrm{bp}$ insert and the $6000 \mathrm{bp}$ backbone. Samples containing the intact plasmid shows a $6400 \mathrm{bp}$ band. Circular DNA is detected in a higher position than expected, because they have a greater agarose gel resistance. A. VL clones (F-VL I/III; R-CL UNI); B. VH clones (F-VH V; R-CH UNI). MW: GeneBio Systems-Ruler 1 kb DNA Ladder Plus.

\subsection{Purification of ch-MAb 4 E12 from Freestyle 293 cells}

Correctly assembled plasmids, with the confirmed sequences to variable domains of the antibody heavy and light chains, were transfected into Freestyle 293-F mammalian cells in different proportions. The mouse-human chimeric IgG1 supernatant samples were collected and purified using protein A columns. The most efficient ch-MAb expression occurred using the same concentration for each recombinant plasmid (Figure 4A). The ch-MAb secreted into supernatant in large scale was purified by affinity chromatography (Figure 4B) followed by gel filtration (Figure S3), resulting in an antibody with a high degree of purity. 
A

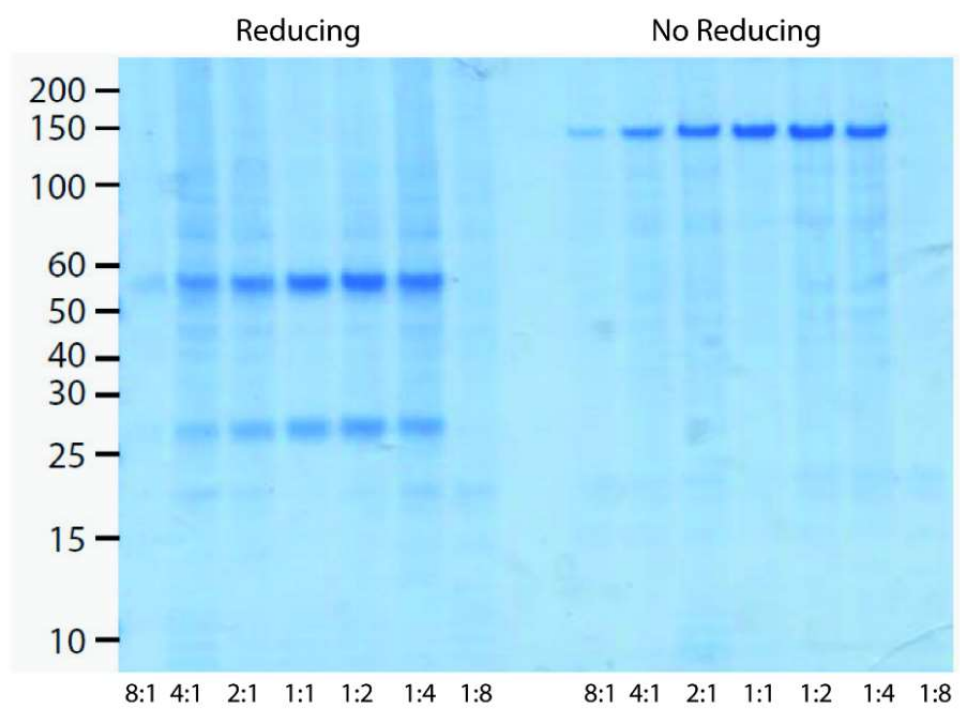

B

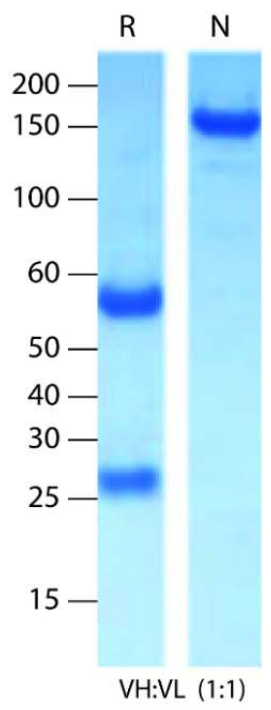

Figure 4. Electrophoretic analysis of ch-MAb 4E12 purified samples. A 1:1 proportion of the recombinant plasmids was selected to ch-MAb expression. Ig heavy and light chains (approximately $56 \mathrm{kDa}$ and $26 \mathrm{kDa}$, respectively) were detected under reducing conditions. A. Fractions purified after small scale expression. B. Mouse-human chimeric antibody purified after large scale expression, SDS-PAGE under reducing $(\mathrm{R})$ or non-reducing $(\mathrm{N})$ conditions.

\subsection{Evaluation of ch-MAb binding and affinity to H. capsulatum HSP60}

A comparison between the mouse-human chimeric antibody and the murine MAb to HSP60 was accomplished. To confirm the maintenence of specificity, H. capsulatum G217B, P. lutzii Pb01, and $P$. brasiliensis $\mathrm{Pb} 18$ yeast cell extracts immunoblotting was performed. The ch-MAb reacted with a protein in the extracts having a molecular weight equivalent to that of Hsp60 with lower sensitivity than the MAb 4E12 (Figure 5A). To quantitatively evaluate the binding to Hsp60, an indirect ELISA was performed. There was a concentration dependent affinity decreasing of ch-MAb to the recombinant protein. The MAb 4E12 binds to rHSP60 with similar affinity at any given antibody concentration (Figure 5B). 
11 of 19

A

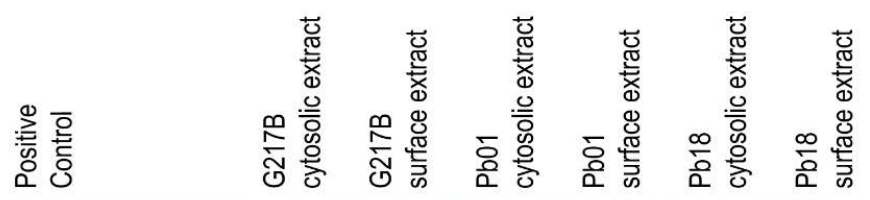

MAb 4E12

ণ ত

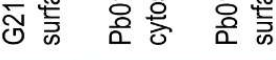

동

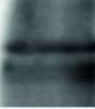

$\longrightarrow$

ch-MAb 4E12

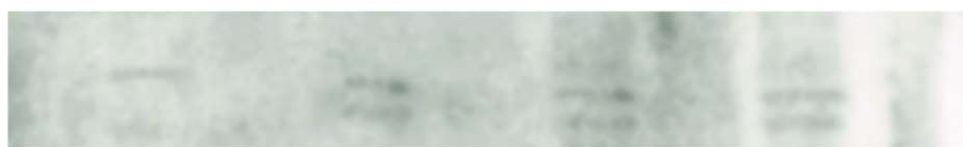

B

Binding to rHSP60

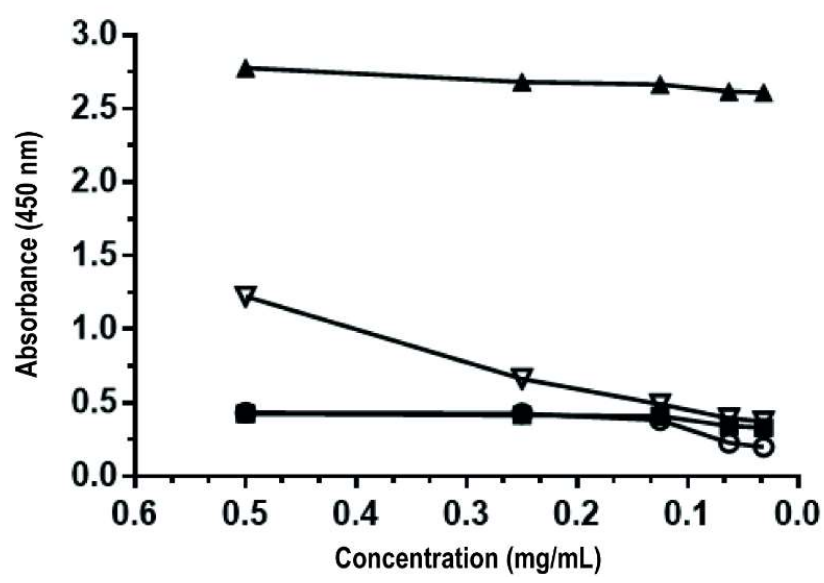

- Blank

$\rightarrow$ Negative Control

$\neg$ MAb 4E12

$\rightarrow$ ch-MAb 4E12

Figure 5. Binding evaluation of the mouse-human chimeric antibody to HSP60. ch-MAb binds to the Hsp60 protein with lower affinity than the MAb 4E12. A. Yeast cell extracts immunobloting. Recombinant Hsp60 was used as positive control. B. Affinity representative curves determined by indirect ELISA. A murine monoclonal antibody anti- $\beta$-glucano (MAb F1.4) was used as negative control. Blank: PBS. MW: TrueColor High Range Protein Marker. 


\subsection{Effects of Hsp60-specific ch-MAbs on H. capsulatum and P. lutzii yeast cells phagocytosis}

The minimum time observed to phagocytosis in vitro was 2 hours in the macrophages THP1 interaction with $H$. capsulatum G217B and 8 hours in the interaction with P. lutzii Pb01. All concentrations significantly increased phagocytosis of $H$. capsulatum G217B and P. lutzii Pb01 yeasts cells compared to the negative control (Figure 6 and Figure 7). The phagocytic capacities were similar after opsonization with ch-MAb 5 or $10 \mu \mathrm{g}$, or with human polyclonal serum against $H$. capsulatum. The phagocytosis percentage in the presence of ch-MAb $50 \mu \mathrm{g}$ increased significantly compared to all groups (Figure S4 and S5) as shown by differential labeling with lysotropic dye and FITC conjugated to the secondary antibody (data not shown). Despite the effectiveness, cells incubated with ch-MAb $50 \mu \mathrm{g}$ showed greater lysis and death. IFN $\gamma$ stimulation increased the uptake of non-opsonized yeast cells.

A

\section{H. capsulatum yeasts phagocytosis by IFN- $\gamma$-non-activated macrophages}

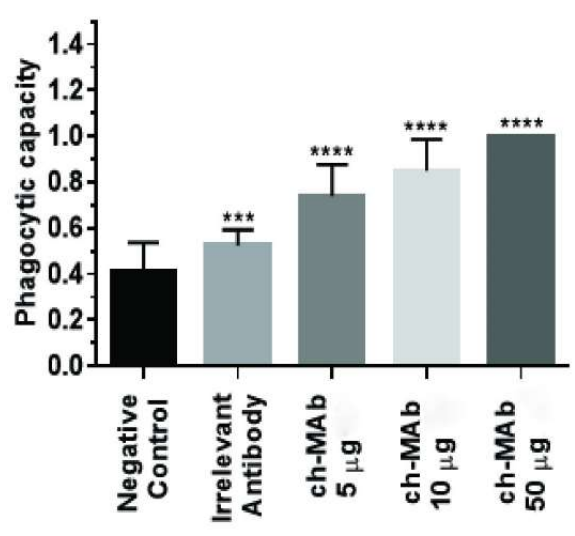

\section{$H$. capsulatum yeasts phagocytosis by} IFN- $\gamma$-activated macrophages

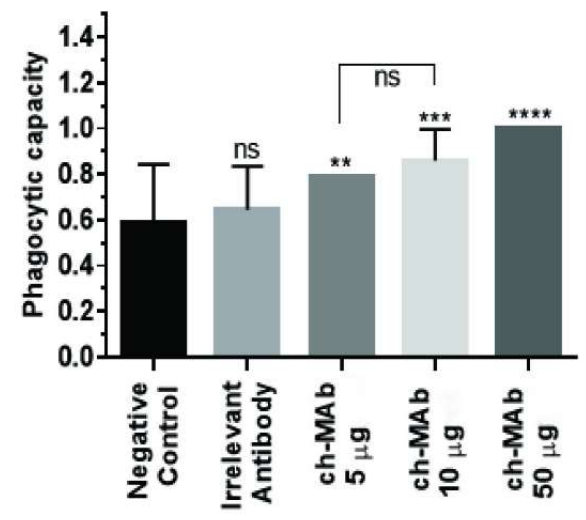

B

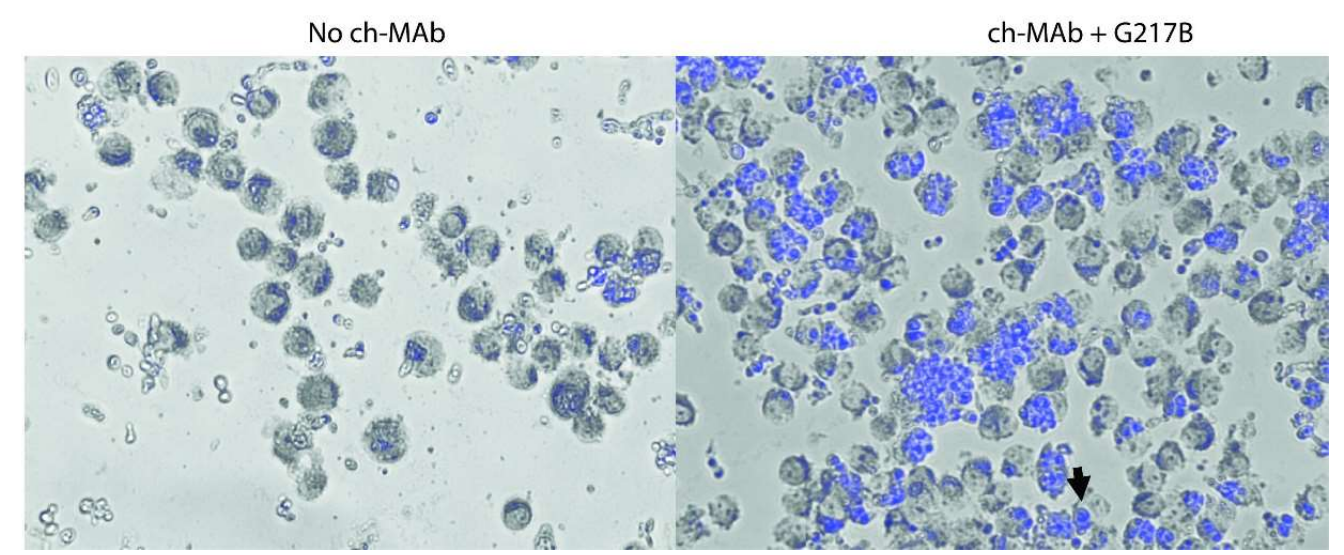

Figure 6. Phagocytosis assay with $H$. capsulatum yeasts. A. Phagocytic capacity (number of phagocytes with internalized yeasts/100 macrophages) in linear scale. Left quadrant: THP1 macrophages without IFN- $\gamma$ stimulation. Opsonization with ch-MAb anti-HSP60 increased phagocytosis of $H$. capsulatum G217B significantly compared to non-opsonized yeast cells. Right quadrant: THP1 stimulated with IFN- $\gamma$, which slightly increased phagocytosis. $\left.(* *) \mathbf{P}<\mathbf{0 . 0 1} ; \mathbf{(}^{* *}\right) \mathbf{P}$ <0.001; (***) P <0.0001; (ns) Not significant. (B) Representative image for phagocytosis assay with H. capsulatum. Left quadrant: Non-opsonized yeast cells. Right quadrant: ch-MAb 4E12-opsonized yeast cells. Arrow indicate macrophage with internalized fungi. Fluorescence Microscopy detection in DAPI Filter (Maximum emission at $461 \mathrm{~nm}$ ). Capture with 20x magnification. 
A $P$. lutzii yeasts phagocytosis by
IFN- $\boldsymbol{\gamma}$-non-activated macrophages

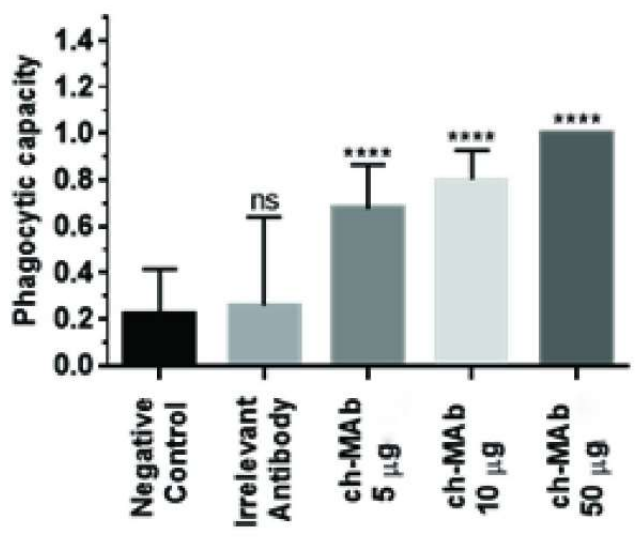

B

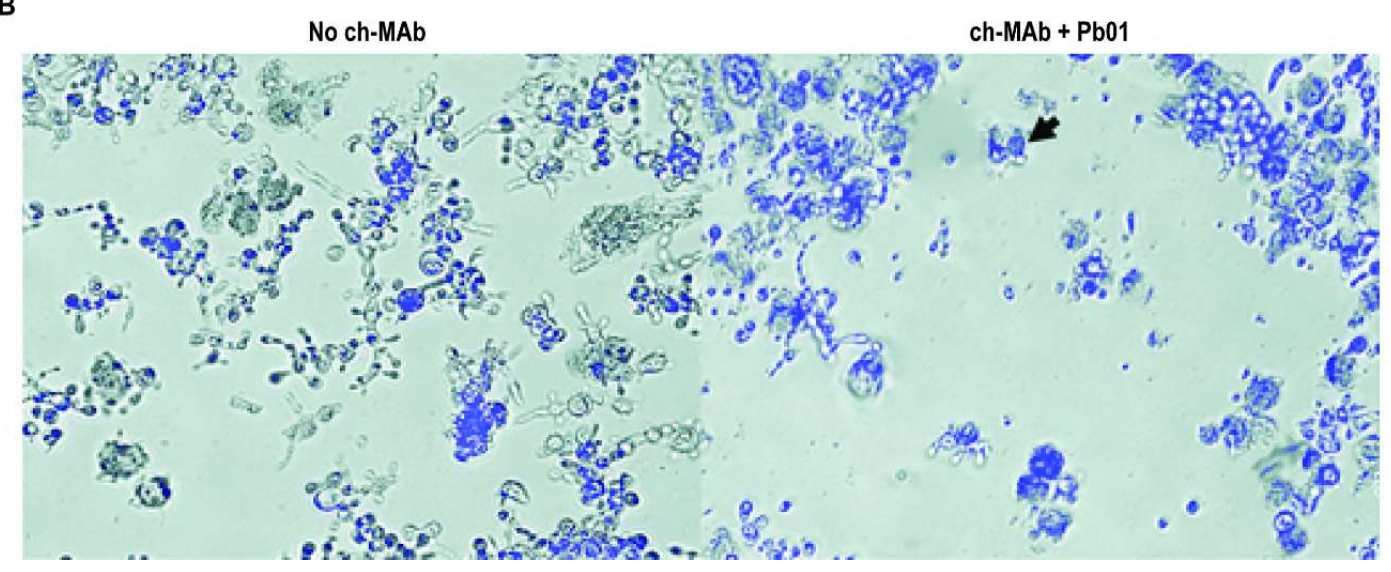

\section{P. lutzii yeasts phagocytosis by} IFN- $\gamma$-activated macrophages

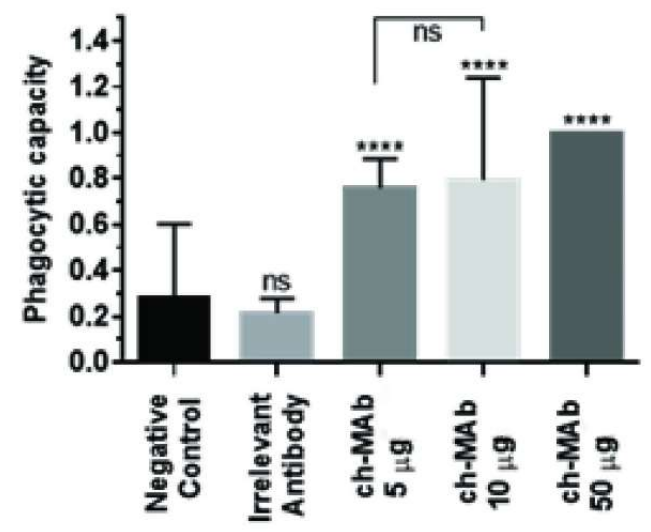

Figure 7. Phagocytosis assay with $P$. lutzii yeasts. A. Phagocytic capacity (number of phagocytes with internalized yeasts/100 macrophages) in linear scale. Left quadrant: THP1 macrophages without IFN- $\gamma$ stimulation. Opsonization with ch-MAb anti-HSP60 increased phagocytosis of $P$. lutzii $\mathrm{Pb} 01$ significantly compared to non-opsonized yeast cells. Right quadrant: THP1 stimulated with IFN- $\gamma$, which slightly increased phagocytosis. $\left.\left.\left(^{* *}\right) \mathrm{P}<0.01 ;{ }^{* * *}\right) \mathrm{P}<0.001 ;{ }^{* * * *}\right) \mathrm{P}<0.0001$; (ns) Not significant. (B) Representative image for phagocytosis assay with P. lutzii. Left quadrant: Non-opsonized yeast cells. Right quadrant: ch-MAb 4E12-opsonized yeast cells. Arrow indicate macrophage with internalized fungi. Fluorescence Microscopy detection in DAPI Filter (Maximum emission at $461 \mathrm{~nm}$ ). Capture with 20x magnification.

\subsection{In vitro evaluation of the Mouse-Human Chimeric Monoclonal Antibody 4 E12 cytotoxicity}

The assay for quantitative analysis of cellular toxicity was based on mitochondrial activity by reducing MTT. The cell viability of THP1 macrophages was preserved above $80 \%$ in the presence of ch-MAb 4 E12 up to $10 \mu \mathrm{g} /$ well. The lethal dose to 50\% (0.5) cell death (LD50) was $50 \mu \mathrm{g} /$ well (Figure $8)$. 


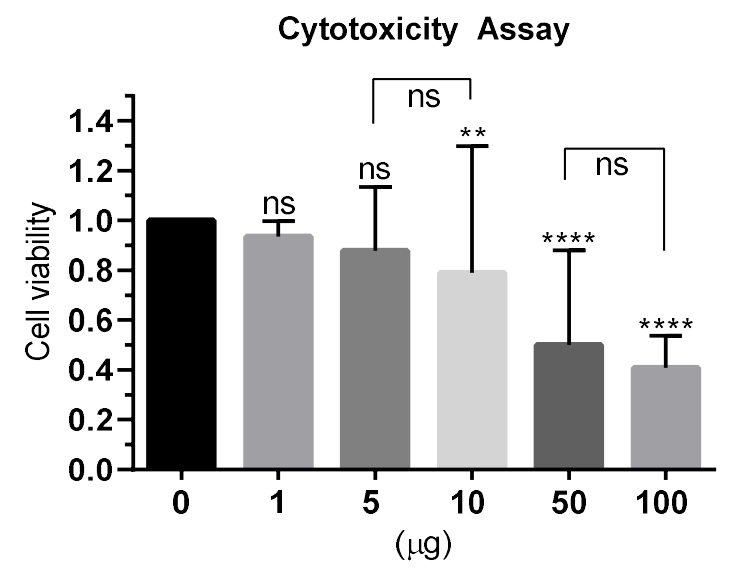

Figure 8. Macrophage cells viability by measuring formazan MTT formation. Samples threated with ch-MAb 1 and $5 \mu \mathrm{g}$ did not lead to significant cell death. Data obtained after cells incubation with different concentrations of ch-MAb 4E12 and comparison with optical density values of cells

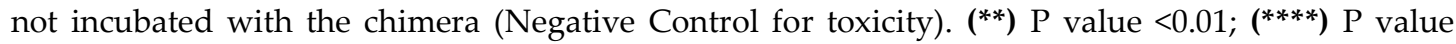
<0.0001; (ns) Not significant. Y Axis: Cell viability (OD from Treated Group/ OD from Control Group Average) in linear scale.

3.8. Preliminary evaluation in vivo of ch-MAb $4 E 12$ acute toxicity using the invertebrate model of Galleria mellonella

To evaluate the acute toxicity of the human-mouse chimeric antibody, G. mellonela larvae were observed for 7 days after treatment with different doses (1-50 $\mu \mathrm{g})$. Groups that received the parental $\mathrm{MAb} 4 \mathrm{E} 12$ at $5 \mu \mathrm{g}$, ch-MAb at $1 \mu \mathrm{g}$, and ch-MAb at $5 \mu \mathrm{g}$, have the same survival percentage $(93.75 \%)$ than negative control groups (No treatment and PBS). Doses of 10 and $25 \mu \mathrm{g}$ reduced the survival to $81.25 \%$, while ch-MAb $50 \mu \mathrm{g}$ reduced the survival to $75 \%$ (Figure 9).

Acute Toxicity in G. mellonela

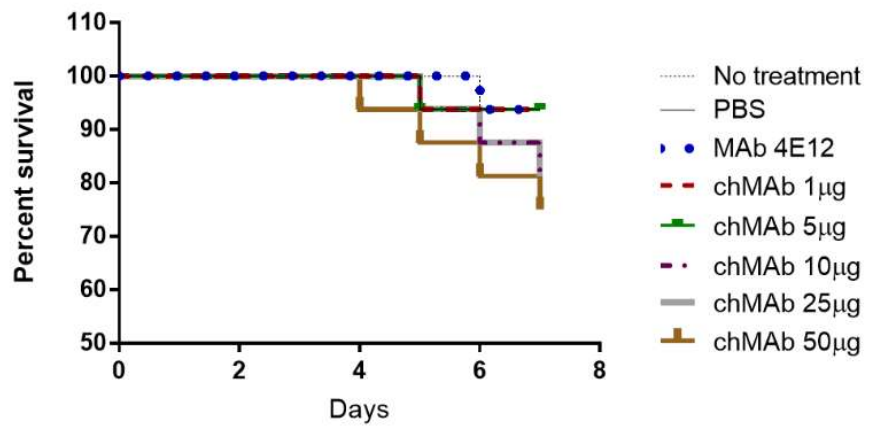

Figure 9. Survival analysis by Kaplan-Meier curve. The curves show a significant trend, $\left(^{*}\right) \mathrm{P}$ value 0.03 , to reduce the survival rate with the administration of doses from ch-MAb $10 \mu g$. Representative graph of two independent experiments.

\subsection{Fungal burden in organs of infected mice}

In vivo protection human-mouse chimeric antibody mediated was evaluated by counting CFU in the lungs (Figure 10A) and spleens (Figure 10B) removed from the animals after 7 days of 
infection. Both groups that received parental MAb 4E12 at $5 \mu \mathrm{g}$ (positive control) and ch-MAb 1 and $5 \mu \mathrm{g}$ had significant reductions in pulmonary and splenic fungal burden compared to the negative control groups. There was no statistically significant difference between CFUs of the group that received no treatment and the group treated with irrelevant antibody.

A

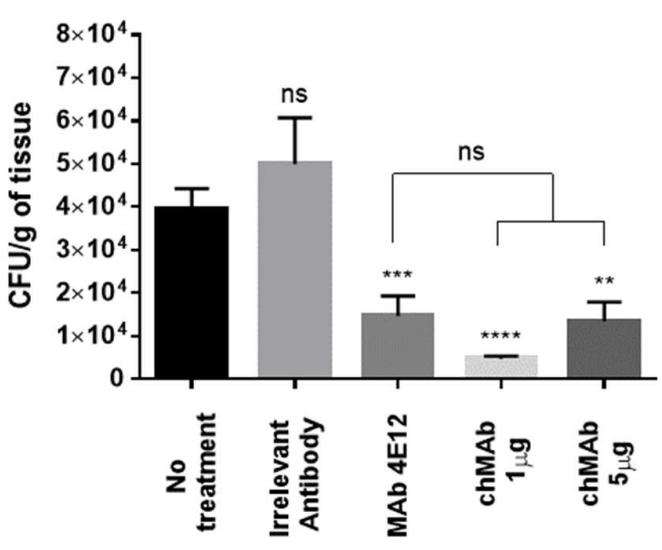

B

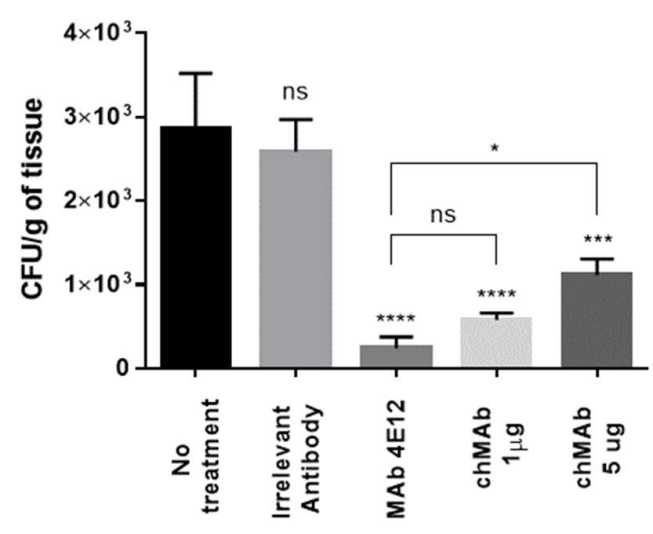

Figure 10. Numbers of CFU in (A) lungs and (B) spleens at 7 days from mice after sublethal intranasal challenge with $5 \times 10^{6} \mathrm{H}$. capsulatum var. capsulatum yeast cells. Intraperitoneal treatment with ch-MAb to Hsp60 at 1 or $5 \mu \mathrm{g}$, similar to $5 \mu \mathrm{g}$ MAb $4 \mathrm{E} 12$ (positive control), significantly reduced the fungal burden in comparison to the negative controls. The groups that received no treatment or an Irrelevant MAb treatment did not shown statistical difference. $\left.(* *) \mathrm{P}<0.01 ; \mathbf{~}^{* * *}\right) \mathrm{P}$

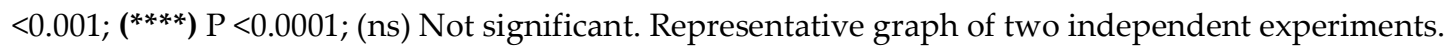

\section{Discussion}

Hsp60 is one of the best-characterized molecules on the surface of H. capsulatum var. capsulatum (26). Guimarães et al. (2009) generated and defined the effectiveness of MAbs to this immunodominant chaperone on the $H$. capsulatum surface (16). Considering the high level of conservation among the Hsp families of dimorphic fungi, particularly among the Hsp60 of $H$. capsulatum and Paracoccidioides spp. (6), Thomaz et al. (2014) also demonstrated that MAbs generated to H. capsulatum Hsp60 can have protective effects in P. lutzii experimental infection model (17). Significantly, the IgG2a $4 \mathrm{E} 12 \mathrm{MAb}$ prolonged survival, reduced fungal burden, and increased phagocytosis in vitro, for both $H$. capsulatum and P. lutzii $(16,17)$. Due to its protective effect in these two fungi, our current work describes the generation and use of IgG1 ch-MAb obtained from the parental MAb 4E12.

The ability to modify the pathogenesis of murine histoplasmosis corresponded to both the Ig subclass and the epitope. Variations in binding by the different MAb isotypes to Hsp60 was quantitatively evaluated by Guimarães et al (2009) using indirect ELISA, with the order of relative reactivity being IgG2a > IgG1 > IgG2b. Interestingly, larger differences were detected between IgG1 subclass MAbs (16). A further study validated these results by determining the equilibrium dissociation constant $\left(\mathrm{K}_{\mathrm{d}}\right)$ between the antibody and HSP60 (P 0.045; Pearson's r 0.89). IgG2a MAbs had the lowest $\mathrm{Kd}$ values $\left(0.035-0.056 \mathrm{~mol}^{-1}\right)$ and the highest affinity to H. capsulatum HSP60, IgG1 
MAbs had intermediate $\mathrm{Kd}\left(0.080 \mathrm{~mol}^{-1}\right)$, followed by the IgG2b isotype with $\mathrm{Kd}$ about twice as high $\left(0.22 \mathrm{~mol}^{-1}\right)$ and the lowest affinity (27).

In the current work, ELISA binding and Immunoblotting assays of MAb 4E12 and ch-MAb 4 E12 with HSP60 confirmed that both antibodies had similar binding characteristics; however, IgG2a $\mathrm{MAb} 4 \mathrm{E} 12$ had a markedly higher affinity than IgG1 ch-MAb 4E12 at the same antigen concentrations. Since MAb 4E12 and ch-MAb 4E12 have identical variable regions, the differences in binding must be a consequence of the switching from IgG2a to IgG1 isotype. It is possible that differences in constant-region sizes, in post-translational process, or in interactions after antigen binding, can result in different types of antigen-antibody complexes, which may change the apparent affinity and fine specificity [Reviewed in (28)].

Despite this reduction in affinity (from 0.14 to 0.46 lower) varying inversely proportional to the concentration, the ch-MAb 4E12 was a potent opsonin of both H. capsulatum and P. lutzii in vitro for PMA-differentiated THP-1 macrophage cells. IFN $\gamma$ stimulation increased the uptake of non-opsonized yeast cells by 1.27 to 1.7 times, although macrophage activation did not seem to influence the phagocytosis effectiveness of ch-Mab 4E12-opsonized yeast cells. The assays resulted in similar phagocytosis percentages of opsonized yeast cells with polyclonal human sera against $H$. capsulatum, ch-MAb at $5 \mu \mathrm{g}$, or ch-MAb at $10 \mu \mathrm{g}$ by THP-1 macrophages. Curiously, all ch-MAb concentrations examined elicited significantly improved yeast cells phagocytosis compared to the polyclonal human sera against P. lutzii. After 8 hours of macrophage-yeast cells interaction, 100\% phagocytosis was observed in the presence of ch-MAb $50 \mu \mathrm{g} /$ well, but this concentration was associated with increased host cell lysis. The highest dose also reduced THP-1 macrophage cells viability in $50 \%$ by MTT assay and decreased G. mellonella motility and survival rate. The larvae also showed alterations of other possible defense mechanisms such as melanization and pupal formation at the high concentration of ch-MAb.

Previous studies also analyzed the parental IgG2a MAb 4E12 effects on phagocytosis compared only to non-opsonized cells and irrelevant antibody-opsonized cells. A concentration of $100 \mu \mathrm{g} / \mathrm{mL}$ of the murine monoclonal antibody significantly enhanced the phagocytosis of $H$. capsulatum by J774.16 macrophage-like cells (16). IgG2a MAb $4 \mathrm{E} 12$ at $50 \mu \mathrm{g} / \mathrm{mL}$ increased the uptake of $P$. lutzii yeast cells by primary peritoneal macrophages from BALB/c mice (17). The experimental doses of IgG2a MAb 4E12 were much higher than those used for IgG1 ch-MAb 4E12 to improve the phagocytosis. It should be considered that the macrophage lineages were different for each assay.

Concentrations were selected for in vivo study of experimental Histoplasmosis after consideration of a ch-MAb 4E12 dose-limiting toxicity assessment and based on previous studies. MAb 18B7, which was used in a phase 1 clinical trial for cryptococcosis, and the mouse-human IgG1 chimeric antibody (ch18B7) against cryptococcal glucuronoxylomannan (GXM), were well tolerated up to doses of $1 \mathrm{mg} / \mathrm{kg}$ in the maximum ( $25 \mu \mathrm{g}$ per mice with $25 \mathrm{~g}$ ) without evidence of toxicity $(13,29)$. In our work, doses of 1 and $5 \mu \mathrm{g}$ showed no toxicity in invertebrate assays or in vitro tests, and were as effective as the parental MAb $4 \mathrm{E} 12$ at $5 \mu \mathrm{g}$ in reducing the fungal burden of mice 7 days after intranasal infection with $H$. capsulatum. Until now, murine parental MAb 4E12 had only been 
tested at a higher dose (500 $\mu \mathrm{g})$ for CFU analysis and after a longer period (60 days) of infection by H. capsulatum, which resulted in no detectable yeast cells in lungs, livers, or spleens (16).

Chimerization and humanization strategies substantially decreases the risk of immunogenicity from non-human antibodies. However, because they maintain murine fragments, mouse-human chimeric antibodies still pose a risk of eliciting an immune response (30). The production of human anti-chimeric antibodies (HACA) has been reported in approximately $40 \%$ of patients (31). Several approaches to humanization have been described that reduce the clinical presence of human anti-humanized antibodies (HAHA) to about $9 \%$ (30). Our in vitro and in vivo work demonstrates that chimeric MAb can be highly effective against dimorphic fungal pathogens. The ch-MAb $4 \mathrm{E} 12$ we report will be further engineered through framework sequences to form a more human structure and then characterized as to their properties to determine whether these novel therapeutics can be applied clinically.

Supplementary Materials: Figure S1: Recombinant HSP60 production in E. coli BL21 DE3., Figure S2: Recombinant HSP60 protein purification steps SDS-PAGE., Figure S3. Elution profile of ch-MAb 4E12 on gel filtration chromatography., Figure S4. Phagocytosis assay with $H$. capsulatum yeast cells using human polyclonal serum as a control., Figure S5. Phagocytosis assay with $P$. lutzii yeast cells using human polyclonal serum as a control. Table S1: PCR primers set used for hybridoma cDNA screening to identify the variable region.

Author Contributions: Conceptualization, C.P.T., J.D.N., J.R.L., S.J.G. and Á.N.D.M.; methodology, C.P.T., J.D.N., Á.N.D.M., L.B.R.S, S.J.G., J.R.L., J.A.Q., F.V.B.; software, Á.N.D.M, S.J.G., and L.B.R.S.; validation, Á.N.D.M, S.J.G., and L.B.R.S.; formal analysis, Á.N.D.M, S.J.G., and L.B.R.S.; investigation, Á.N.D.M., S.J.G., L.B.R.S, D.W., F.V.B.; resources, C.P.T., J.D.N., J.R.L., S.C.A., S.J.G.; data curation, Á.N.D.M.; writing-original draft preparation, Á.N.D.M.; writing - review and editing, Á.N.D.M., C.P.T., J.D.N., S.C.A., S.J.G.; visualization, Á.N.D.M, S.J.G., and L.B.R.S.; supervision, C.P.T and J.D.N.; project administration, C.P.T.; funding acquisition, C.P.T. All authors have read and agreed to the published version of the manuscript.

Funding: This research was funded by Fundação de Amparo à Pesquisa do Estado de São Paulo (FAPESP), grant number 2016/08730-6, CNPq, grant number 420480/2018-8, Coordenação de Aperfeiçoamento de Pessoal de Nível Superior - CAPES

Acknowledgments: Our thanks to Dr. Joshua D. Nosanchuk and Dr. Steven C. Almo for kindly giving up their laboratory and having reagents to carry out part of the experiments. Thanks to Leandro B. Roque da Silva for his contribution with FAPESP scholarship 2018/201771-6.

Conflicts of Interest: The authors declare that they have no conflict of interest.

\section{References}

1. Ulrich S, Ebel F. Monoclonal Antibodies as Tools to Combat Fungal Infections. [cited 2020 Jul 28]; Available from: www.mdpi.com/journal/jof

2. Goughenour KD, Rappleye CA. Antifungal therapeutics for dimorphic fungal pathogens [Internet]. Vol. 8, Virulence. Taylor and Francis Inc.; 2017 [cited 2020 Jul 30]. p. 211-21. Available from: https://www.tandfonline.com/doi/abs/10.1080/21505594.2016.1235653

3. Kauffman CA. Histoplasmosis: A clinical and laboratory update. Vol. 20, Clinical Microbiology Reviews. 2007. p. 115-32.

4. Travassos LR, Taborda CP. New advances in the development of a vaccine against paracoccidioidomycosis. Front Microbiol. 2012 Jun;3.

5. Martinez R. New Trends in Paracoccidioidomycosis Epidemiology. J Fungi. 2017 Jan;3(1):1. 
6. Soares R de BA, Gomez FJ, Soares CM de A, Deepe GS. Vaccination with Heat Shock Protein 60 Induces a Protective Immune Response against Experimental Paracoccidioides brasiliensis Pulmonary Infection. Infect Immun. 2008 Jan;76(9):4214-21.

7. Rauseo AM, Coler-Reilly A, Larson L, Spec A. Hope on the horizon: Novel fungal treatments in development [Internet]. Vol. 7, Open Forum Infectious Diseases. Oxford University Press; 2020 [cited 2020 10]. Aug from: https:/academic.oup.com/ofid/article/7/2/ofaa016/5700872

8. Seyedmousavi S, Rafati H, Ilkit M, Tolooe A, Hedayati MT, Verweij P. Systemic antifungal agents: Current status and projected future developments. In: Methods in Molecular Biology [Internet]. Humana Press Inc.; 2017 [cited 2020 Jul 31]. p. 107-39. Available from: https://pubmed.ncbi.nlm.nih.gov/27837500/

9. Polvi EJ, Li X, O'Meara TR, Leach MD, Cowen LE. Opportunistic yeast pathogens: Reservoirs, virulence mechanisms, and therapeutic strategies. Cell Mol Life Sci [Internet]. 2015 Jun 26 [cited 2020 Jul 31];72(12):2261-87. Available from: http://link.springer.com/10.1007/s00018-015-1860-z

10. Denning DW, Hope WW. Therapy for fungal diseases: Opportunities and priorities [Internet]. Vol. 18, Trends in Microbiology. 2010 [cited 2020 Jul 31]. p. 195-204. Available from: https://linkinghub.elsevier.com/retrieve/pii/S0966842X10000211

11. Xie JL, Polvi EJ, Shekhar-Guturja T, Cowen LE. Elucidating drug resistance in human fungal pathogens [Internet]. Vol. 9, Future Microbiology. Future Medicine Ltd.; 2014 [cited 2020 Jul 31]. p. 523-42. Available from: https://www.futuremedicine.com/doi/10.2217/fmb.14.18

12. Casadevall A, Pirofski LA. Immunoglobulins in defense, pathogenesis, and therapy of fungal diseases. Vol. 11, Cell Host and Microbe. Elsevier Inc.; 2012. p. 447-56.

13. Larsen RA, Pappas PG, Perfect J, Aberg JA, Casadevall A, Cloud GA, et al. Phase I evaluation of the safety and pharmacokinetics of murine-derived anticryptococcal antibody $18 \mathrm{~B} 7$ in subjects with treated cryptococcal meningitis. Antimicrob Agents Chemother. 2005 Mar;49(3):952-8.

14. Garbe TR. Heat shock proteins and infection: Interactions of pathogen and host. Experientia. 1992 Jul;48(7):635-9.

15. Kaufmann SH. Heat shock proteins and the immune response. Immunol Today. 1990 Apr;11(4):129-36.

16. Guimarães AJ, Frases S, Gomez FJ, Zancopé-Oliveira RM, Nosanchuk JD. Monoclonal Antibodies to Heat Shock Protein 60 Alter the Pathogenesis of Histoplasma capsulatum. Infect Immun. 2009 Apr;77(4):1357-67.

17. Thomaz L, Nosanchuk JD, Rossi DCP, Travassos LR, Taborda CP. Monoclonal antibodies to heat shock protein 60 induce a protective immune response against experimental Paracoccidioides lutzii. Microbes Infect. 2014 Sep;16(9):788-95.

18. Torres M, Fernandez-Fuentes N, Fiser A, Casadevall A. Exchanging murine and human immunoglobulin constant chains affects the kinetics and thermodynamics of antigen binding and chimeric antibody autoreactivity. PLoS One [Internet]. 2007 Dec 12 [cited 2020 Aug 10];2(12):1310. Available from: /pmc/articles/PMC2110899/?report=abstract

19. Gomez FJ, Allendoerfer R, Deepe GS. Vaccination with Recombinant Heat Shock Protein 60 from Histoplasma capsulatum Protects Mice against Pulmonary Histoplasmosis. Infect 
Immun [Internet]. 1995 [cited 2021 Apr 1];63(7):2587-95. Available from: http://iai.asm.org/

20. Kabat E. Sequences of proteins of immunological interest. 5th ed. Bethesda MD: U.S. Dept. of Health and Human Services Public Health Service National Institutes of Health; 1991.

21. Nicholls PJ, Johnson VG, Blanford MD, Andrew SM. An improved method for generating single-chain antibodies from hybridomas. J Immunol Methods [Internet]. 1993 Sep 27 [cited 2020 Feb 29];165(1):81-91. Available from: http://www.ncbi.nlm.nih.gov/pubmed/8409471

22. Mazor Y, Barnea I, Keydar I, Benhar I. Antibody internalization studied using a novel IgG binding toxin fusion. J Immunol Methods. 2007 Apr 10;321(1-2):41-59.

23. IgBlast tool [Internet]. [cited 2020 Jul 23]. Available from: https://www.ncbi.nlm.nih.gov/igblast/

24. IMGT/V-QUEST [Internet]. [cited 2020 Jul 23]. Available from: http://www.imgt.org/IMGT_vquest/vquest?livret=0\&Option=humanIg

25. SignalP-5.0 [Internet]. [cited 2020 Jul 24]. Available from: http://www.cbs.dtu.dk/services/SignalP/

26. Long KH, Gomez FJ, Morris RE, Newman SL. Identification of Heat Shock Protein 60 as the Ligand on Histoplasma capsulatum That Mediates Binding to CD18 Receptors on Human Macrophages . J Immunol. 2003 Jan 1;170(1):487-94.

27. Guimarães AJ, Frases S, Pontes B, De Cerqueira MD, Rodrigues ML, Viana NB, et al. Agglutination of Histoplasma capsulatum by IgG monoclonal antibodies against Hsp60 impacts macrophage effector functions. Infect Immun [Internet]. 2011 Feb 1 [cited 2020 Sep 21];79(2):918-27. Available from: http://iai.asm.org/

28. Janda A, Bowen A, Greenspan NS, Casadevall A. Ig Constant Region Effects on Variable Region Structure and Function. Front Microbiol [Internet]. 2016 Feb 4 [cited 2020 Sep 24];7(FEB):22. Available from: http://journal.frontiersin.org/Article/10.3389/fmicb.2016.00022/abstract

29. Zebedee SL, Koduri RK, Mukherjee J, Mukherjee S, Lee S, Sauer DF, et al. Mouse-human immunoglobulin G1 chimeric antibodies with activities against Cryptococcus neoformans. Antimicrob Agents Chemother [Internet]. 1994 [cited 2021 Mar 23];38(7):1507-14. Available from: https://pubmed.ncbi.nlm.nih.gov/7979280/

30. Bernett MJ, Karki S, Moore GL, Leung IWL, Chen H, Pong E, et al. Engineering Fully Human Monoclonal Antibodies from Murine Variable Regions. J Mol Biol [Internet]. 2010;396(5):1474-90. Available from: http://dx.doi.org/10.1016/j.jmb.2009.12.046

31. Hwang WYK, Foote J. Immunogenicity of engineered antibodies. Methods. 2005 May;36(1):3-10. 